\title{
Wellbeing and Worldbuilding: The Science Fiction of Wellbeing Measurement
}

\section{Weighing Wellbeing}

What is wellbeing? The powerful often express concern for the wellbeing of those in their power. For example, bosses claim to care for the wellbeing of workers, landlords for the wellbeing of tenants, politicians for the wellbeing of members of the public. A cat who is knocking a mouse from claw to claw may well (with his tail) be emailing that mouse Ten Top Wellbeing Tips. So it is tempting, once you realise that 'wellbeing' is instrumental in shoring up worlds filled with ill-being, to reject the concept altogether. This chapter takes another approach. Although the rhetoric of wellbeing has been enthusiastically embraced by the neoliberal state and the neoliberal firm, there is more to the concept than such endorsements suggest. The concept has roots in moral philosophy, welfare economics, positive psychology, and environmental sustainability. In other words, it is grounded in debates around the nature of the good life; in the recognition that traditional broad measures of economic progress such as Gross Domestic Product (GDP) fail to capture the complexity of freedom and flourishing; in the recognition that health means much more than merely the absence of pathology; and in a holistic concern for a complex, interconnected, more-than-human world (including cats and mice).

Wellbeing is clearly difficult to define and to measure. But this point might also be reversed. What if we consider these very difficulties — difficulties of definition and measurement - to continually create and re-create the concept of wellbeing? When policymakers or practitioners seek to measure and to cultivate wellbeing, they necessarily grapple with the challenge of quantifying what 'really matters,' what is 'ultimately' valuable. Shaped and reshaped by this elusive aim, wellbeing has evolved into a fragmented, contextual, and multi-dimensional construct, underpinned by numerous measurement methodologies at many different scales, usually pulling in factors such as physical and mental health, happiness, ecological sustainability, social connectivity, sense of purpose, and the cultivation and realisation of capabilities for 'flourishing.' 
So what exactly are the difficulties associated with defining and measuring wellbeing? One perennial theme within the literature is how to integrate wellbeing data from different sources, and make it legible to policy evaluation denominated in currency. Attempts to formulate 'universal' frameworks for wellbeing assessment have also clashed with aspirations to democratically develop measurement practices sensitive to 'local' priorities (McGregor 2018, 197). There are also debates about different methods of eliciting subjective wellbeing information ('How are you?' is a complicated question), and about how data collection can interfere with wellbeing interventions ('How are you now?' can be a stressful question). More broadly, there are questions around measurement as a transformative tool, versus measurement which attempts to leave the measured phenomena as unaltered as possible. ${ }^{1}$ The wellbeing literature also grapples with what is 'off limits,' what it would be foolish and self-defeating to try to define and to measure. For instance, as Parth Dasgupta suggests in a 2021 report for the UK government:

Many would argue as well that to model human behaviour formally, let alone mathematically, is to tarnish the human experience, with all its richness. And yet, economists in governments, international organisations, and private corporations find those models and their adaptations essential for collecting and analysing data, forecasting economic trajectories, evaluating options and designing policy. (Dasgupta 2021, 6)

Or as Kim Stanley Robinson muses in The Ministry for the Future (2020), “it's important also to take this whole question back out of the realm of quantification, sometimes [...] To acknowledge the reality of other people, and of the planet itself. To see other people's faces. To walk outdoors and look around" (Robinson 2020, 89). What all this means is that to explore wellbeing through science fiction and fantasy (SFF), we don't just need SFF about health and happiness. We also need SFF about measurement: SFF that explores surveillance, data infrastructures, the political economy of personal data, 'the metric gaze,' social analytics, and the social life of metrics (Beer 2016, 30). We need SFF about algorithmic governance, gamification, surveillance, persuasion architectures; SFF

\footnotetext{
${ }^{1}$ Science fiction and fantasy (SFF) is characterized by comparable tensions. SFF has a paradoxical capacity to reinforce dominant ideology, while also contemplating diverse worlds an epistemologically enlarging manner. SFF also contradictory aspirations to speak about the future as though enjoying privileged access to something predetermined, while also performatively shaping that future.
} 
about expert elicitation, preferences and utility, contingent valuations and revealed preferences; SFF about more-than-human cognitive systems, and about a vast variety of deliberative and democratic institutions and their relationship to recent transformations in techno-capital.

That is a lot. This brief chapter hopes only to lay groundwork for future study and debate. It explores just a few linkages between wellbeing, measurement, and SFF, mainly emphasising dystopian fiction. Has SFF struggled to imagine wellbeing policy — or any holistic stance on the myriad factors that inform the happiness and flourishing of populations - except where the interested party is some sinister elite? Perhaps some paternalistic and unaccountable government, or some clandestine sect of eugenicists like the Bene Gesserit of Frank Herbert's Dune (1965)? Without pretending to any comprehensive answer, this chapter tentatively suggests that this may be the case. ${ }^{2}$ It concludes with brief reflection on how the measurement of wellbeing builds worlds. And so to begin with some historical context, we can start with the best of all possible worlds.

\section{Proto-Dystopia and Optimistic Theodicy}

SFF critics love to discover traces of utopia in the unlikeliest places, including dystopias. The trick often is to attend to hope, and to the worlds implied by such hope. Ernst Bloch's Principle of Hope (1954-1959) is often taken as a critical departure point, in a tradition that leads through Darko Suvin and Tom Moylan among others. But as Voltaire's Candide (1759) shows us, the critical practice of teasing something wonderful from suffering and vice finds an earlier precedent in optimistic theodicy. Optimistic theodicy, which briefly flourished in the Eighteenth Century, tried to answer the problem of evil — 'If God knows everything, can do anything, and is infinitely good, then how does one explain evil?' - by proposing that evil in some parts of Creation is an absolutely necessary

\footnotetext{
${ }^{2}$ One area worth further exploration is epic fantasy. Works such as Anne McCaffrey's Moreta: Dragonlady of Pern(1983) and Tamora Pierce's Briar's Book (1999) explore themes such as plagues, quarantine, sanitation, mass vaccination, the influence of socio-economic inequality on health outcomes, and the perils of improperly regulated scientific (magical) research. Lengthy sieges in works like Mary Gentle's Ash: A Secret History (2000), Umberto Eco's Baudilino (2002), or K.J. Parker's Sixteen Ways to Defend a Walled City (2019) dramatise the protection and management of imperilled populations. Magic in works by Robin Hobb, N.K. Jemisin, Ursula K. Le Guin, Vonda N. McIntyre, Brandon Sanderson, and others fantastically reimagine human health and healing within a broader ecological framework and — insofar as such magic systems are concerned with debts, prices, side-effects, balance, resource management, stocks and flows, contracts and the like — within an economic framework too. Lois McMaster Bujold's The Physicians of Vilnoc(2020) is a richly intriguing specimen. The sorcerer Penric is a medical detective posed with the epidemiological puzzle of a new plague, centred on a military outpost. The social dimension of public health is prominent, as Penric proactively manages the risks of rumours, superstition, and panic.
} 
condition for greater good elsewhere. ${ }^{3}$ Over the course of Candide the titular hero, his optimistic tutor Pangloss, and their friends and associates, all endure the most savage misery and misfortune. But by the end the indefatigable Pangloss is still gamely trying reframe all this suffering as necessary ingredients in the best of all possible worlds. Far from fanning revolutionary sparks, Pangloss's hopewashing merely justifies a calamitous status quo. Of course, Pangloss is at least theorising about pain he has shared, not somebody else's pain. But optimistic theodicy was often the provenance of patrician privilege: "Poverty," writes the Tory MP Soame Jenyns, "or the want of riches, is generally compensated by having more hopes" (Jenyns 1758, 32).

For our purposes, a key point is that Pangloss's ruminations always involve a 'best' of all possible worlds, and thus by implication a second-best, a third-best, and so on. In other words, myriad forms of value get treated as though they can be collapsed into one form, allowing the value of different total states of affairs to be calculated and arranged on a leaderboard. Of course, even allowing the dubious idea that diverse forms of value are commensurable within one person's life, it does not follow that valid calculations can be made across a society, let a whole world. A few decades later, when Jeremy Bentham was establish utilitarianism as a systematic philosophy, he confessed (albeit in unpublished papers) to just this fragility in his project's foundations:

[...] one man's happiness will never be another man's happiness; a gain to one man is no gain to another; one might as well pretend to add twenty apples to twenty pears, after which you had done that could not be forty of any one thing but twenty of each just as they were before.

(Bentham in Halévy 1928: 495)

Still, Bentham continues, do we really have a choice? Unless we make-believe that the apples are pears, or vice-versa, all political reasoning will grind to a halt. ${ }^{4}$ The large, complex, interconnected societies of modernity seem to demand some kind of calculative moral reasoning. So we find ourselves forced to measure things that can't really be measured, and to add together things that can't really be added together. In his 1781 An Introduction to the Principles of Morals and Legislation,

\footnotetext{
${ }^{3}$ As Soame Jenyns puts it, "to produce good, exclusive of evil, is one of those impossibilities, which even infinite power cannot accomplish" (Jenyns 1758, 5). Optimistic theodicy is strongly, but a little unfairly, associated with G.W. Leibniz and his "le meilleur des mondes possibles." The theodician arguments by Origen, Irenaeus, Al-Ghazali, Ibn Taymiyya, among others, are also of some relevance.

${ }^{4}$ But when we add up these incommensurable things, should we be pretending there are now forty pears, or forty apples? Or perhaps five apples and thirty-five pears? What algorithms to use? What possible grounds are there to decide?
} 
Bentham lays out principles that would later become known as felicific calculus, apparently proposing that decision-makers quite literally assign numbers to different facets of potential pleasure and pain: "Sum up the values of all the pleasures on one side and of all the pains on the other [...] Repeat the above process with respect to each person whose interests appear to be concerned; and then sum the results" (Bentham 2000 [1781], 32). The way to conduct such 'measurements' is to pluck numbers from thin air, based on precedent and intuition. Then again, would this really be so preposterous? Given that the other major concerns of Bentham's Introduction are crime and punishment, perhaps it wouldn't. Bentham knows that translating the good and evil of an action into a number is something that sentencing judges do all the time, when they establish the magnitude of a fine or prison sentence. But this focus on the judgments of qualified experts, with at least some small degree of implied fallibility and accountability, was soon to disappear.

\section{Classic Dystopia and Social Utility}

Around the turn of the century, as science fiction was emerging from scientific romance, economics was also emerging from political economy. Aligned to economics' aspiration to scientific objectivity, the concept of 'utility' gained prominence and conceptual refinement, offering a workaround for measuring things that can't be measured, and adding together things that can't be added. You might suppose that (as a sort of successor to Bentham's felicific calculus) utility would be the locus of a rich plurality of conceptions of health, happiness, and the good life. Early welfare economics was, after all, concerned with how one gets from myriad individual preferences to a general social utility function. You might therefore anticipate fierce debate about the scope of admissible sub-utilities, about their relative weightings, about the methods appropriate to elicit the value of each, and about the systems of consultation, scrutiny and appeal in which to embed those methods. ${ }^{5}$ Such suppositions would be wrong. In fact, the notion of utility that dominated up until at least the mid-century was much narrower. Economists such as Lionel Robbins, Paul Samuelson, and Kenneth Arrow developed understood utility in close connection with what they supposed could be objectively measured. What that boiled down to was market transactions. ${ }^{6}$

\footnotetext{
${ }^{5}$ You might suppose, of course, many of the arguments marshalled in such debates to be predictably horrifying as regards gender, race, class, disability, sexuality, psychology, ecology, and in other ways.

${ }^{6}$ In practice, many welfare economists did slip into talking about 'utility' as though it were some unassailable desideratum: as though it referred to welfare, happiness, usefulness, or eudaimonia, rather than merely a mathematical property of transactional data. It was often when their reasoning about utility led them toward inconveniently radical conclusions, that they suddenly remembered that utility was not necessarily good.
} 
The so-called 'classic' dystopian tradition, which emerged over this same period, for the most part rehearsed the same impoverished imaginary as early welfare economics, one which mostly precluded radical democratic possibility. It included works such as H.G. Wells's The Time Machine (1885), E.M. Forster's ‘The Machine Stops’ (1909), Rose Macauley's What Not (1918/1919), Yevgeny Zamyatin's We (1921), Aldous Huxley's Brave New World (1932), and George Orwell's Animal Farm (1945) and Nineteen Eighty-Four (1949). These are stories about bad societies. When they do invoke the wellbeing of the collective, they place its management squarely in the hands of authoritarian social engineers, and well beyond the scope of democratic governance. Measurement is, accordingly, a matter of top-down surveillance, which seldom if ever involves community deliberation or participatory self-transformation. Measurement may sometimes also be propagandistic theatre, unconstrained by empirical methodology: "For example, the Ministry of Plenty's forecast had estimated the output of boots for the quarter at 145 million pairs [...] Very likely no boots had been produced at all. Likelier still, nobody knew how many had been produced, much less cared” (Orwell 1949).

'Be happy ... or else!' is often their implicit slogan, and their inhabitants often all too aware their happiness is a sham. Then again, there are also those who really are having a nice time, and who really do believe (fervently or tentatively) that they are leading a fulfilling and good life. The problem is that they have had an untenable model of wellbeing imposed upon them. For example, they may have many capabilities that they don't even realise are being suppressed. They may have grown accustomed to fleeting and perilous existence. Their affect and cognition may be pharmacologically grounded in ways which invite readers to question its authenticity. The authorities may be keeping them in the dark about the disastrously ecologically unstable foundations of their society. And of course, their happiness may secretly but straightforwardly depend on somebody else's suffering.

Crucially, all this may be quite consistent with the population being shaped to be in some sense happy, fit, strong, productive, appetitive, sociable, politically engaged, and/or intelligent (or else). Kurt Vonnegut's Player Piano (1952), for example, depicts a dystopia based on psychometrics and automation; as one insightful character observes, this society is ordered not just on brain power, but "on special kinds of brain power. Not only must a person be bright, he must be bright in certain approved, useful directions" (xx). The eugenicist dystopia of Rose Macauley’s What Not (1918/1919) 
gives a rather neat illustration of Foucault's distinction between sovereign power as merely repressive, and biopower that grasps life to stimulate, multiply, and administer it:

There were numerous and complicated regulations on the subject, which could not, of course, be enforced; the Ministry's methods were those of stimulation, reward and punishment, rather than of coercion. There were bonuses on the births of the babies of parents conforming to the regulations, and penal taxes on unregulated infants, taxes increasing in proportion to the flagrancy of the parents' disobedience, so that the offspring of parents of very low mental calibre brought with them financial ruin. Everyone held a Ministry of Brains form, showing his or her mental category, officially ascertained and registered.

Classic dystopia frequently reimagines social utility in inauthentic and fallen forms. In What Not, an advert for a Government Course in Mind Training presently reveals what counts as 'clever' to the Ministry of Brains. One financier's testimonial reads: "Since I began the Course I have doubled my income and halved those of 750 others. I hope, by the time I have completed the Course, to have ruined twice this number" (29). A poet, now intelligent enough to find rhymes for all their lines, brags about giving up free verse. In Kendall Foster Crossen's Year of Consent (1954), the supercomputer Herbie ensures that citizens are empowered to vote for whomever they prefer, but not to prefer whomever they prefer: "when the administration wanted to make a new move, they knew exactly how to condition the people so that it would be backed. [...] This, then, was government by consent" (Crossen 1954, 32). In Wells's The Time Machine, humans eradicate disease ... but in a bad way, since it goes hand-in-hand with the waning of human capabilities: "What, unless biological science is a mass of errors, is the cause of human intelligence and vigour?" In Huxley's Brave New World, even the desirability of universal happiness is drawn into question:

“But I don't want comfort. I want God, I want poetry, I want real danger, I want freedom, I want goodness. I want sin.”

"In fact," said Mustapha Mond, "you're claiming the right to be unhappy."

"All right then," said the Savage defiantly, "I'm claiming the right to be unhappy." 
Indeed, surveillance and biopower may acquire speculative form precisely to the extent necessary to undermine the authority's account of human perfectibility. In this, classic dystopia was eager to elevate the plurality of human subjectivity above the predatory high modernisms of fascism and Soviet communism. Many cast a satirical eye on Fordist capitalism as well. They afforded glimpses of the constructed and contingent character of a world based on money and markets, though generally saving their most biting satire for the state's role in deforming humans into homo economicus. In these respects, their stubbornly topsy-turvy accounts of social utility are resonant with later postcolonial, queer and feminist thinking about the transformative potentials of 'negative' affect, and about resisting the normative power of 'positive' affect.

Nevertheless, broadly speaking, classic dystopia cultivated the idea that humans are so richly idiosyncratic that we are incapable of collective decision-making about social utility. Of course, we can fumble our way to some aggregation of preferences - those democratic elections in Crossen's Year of Consent, for example? — but seldom on any philosophically robust basis. The deep fear that animated many of these works was that whenever we try to do better, and treat ourselves as legible, evaluable, and available for calculative rationality, existentially devastating violence will be unleashed. This fear eased up considerably whenever the dehumanising machine in question was not a government, but the larger and more dispersed assemblage of capitalism.

\section{Ambiguous Heterotopia and Capabilities-Based Wellbeing}

Welfare economics transformed fundamentally from the 1970s onward, in no small part due to Amartya Sen's patient and persuasive refutation of revealed preference theory as it then existed, and his work developing a capabilities-based approach to welfare. Such an approach clearly recognises that dropping below a minimal threshold in some important dimension of welfare can't simply be compensated by improvement in another. It focuses on expanding a person's "actual ability to do the different things a person has reason to value doing or being” (Sen 2009, p.16). Around the same time, within healthcare economics, Quality Adjusted Life Years (QALYs) emerged as a tool for assessing and comparing health policies and interventions, using questionnaires to quantify quality of life across various states of health. Gradually welfare economists and social choice theorists began to accept that our democratic imaginary did not have to be limited to the kinds of information flows constitutive of elections and markets, but could legitimately involve a much more varied set of 
factors: human rights, happiness, health, equality, dignity, capabilities, environmental sustainability, and many others. Or, to use the increasingly popular umbrella term, wellbeing. Nevertheless, this period also saw the demise of embedded liberalism and the emergence of neoliberalism, a diverse panoply of projects of dispossession and enclosure, homogeneously disguised as 'deregulation' and the expansion of 'the free market.'

Literary critics including Raffaella Baccolini and Tom Moylan identify works such as Margaret Atwood's The Handmaid's Tale (1985), P.D. James's The Children of Men (1992), Lois Lowry's The Giver (1993) and Octavia E. Butler's Parable of the Sower (1993), as 'critical dystopias,' insofar as they refuse to dramatise the futility of dissent, but rather embrace ambiguity and the possibility of revolutionary transformation. Whereas the classic dystopia tends to imply, 'We'd better not let this happen, or there will be no way out!' the critical dystopia says, 'This is already at least a little how things are; but believe it or not, there is still hope. ${ }^{7}$ Yet the preoccupation of the classic dystopians, that quantified publics are unprotected from conquest by society's authoritarian elements, continued to shape decisively how these critical dystopias formulated such hope. As the next section will suggest, this seems still to be true of contemporary data dystopias of the 21 st Century.

Likewise, while critical utopias like Ursula K. Le Guin's The Dispossessed: An Ambiguous Utopia (1974) and Marge Piercy's Woman on the Edge of Time (1978) emphasised participatory democracy as a way of mutualising wellbeing, quantification was usually either absent or present as a necessary evil, perhaps the first stirrings of a nascent state. Samuel R. Delany's Trouble on Triton: An Ambiguous Heterotopia (1976) was one novel which tried to imagine a relative strong and pervasive state along with with greater social, economic, and political freedoms, both formal and substantive. Triton is an unusual democracy: everyone is governed by the candidate they vote for. Living arrangements are various and often communal. Society appears fairly heavily surveilled, although it may be that the majority of the data is never used. Intriguingly, Delany also imagines an intellectual discipline, 'metalogic,' which expands the realm of the calculable; a metalogician is likely to work in something called a 'computer hegemony.' We are not told explicitly how all these features of Tritonese society connect. What we

\footnotetext{
7 'At least a little': and such dystopias are at risk of disguising specific distributions of violence and in particular their racist and colonial character. It's also worth mentioning that no one seriously intends this distinction or periodisation between classic and critical dystopia completely rigidly: there are plenty of glimpses of hope in the work of Wells, Forster, Macaulay et al.; conversely, while dystopias of Atwood, Butler, James, Lowry et al. award happy endings to few rebellious subjects, this might be seen as resilient dystopias spitting out dangerous antigens. Nor are critical dystopias and critical utopias rigidly distinct: exemplary critical utopias such as Ursula Le Guin's The Dispossessed: An Ambiguous Utopia (1974) and The Eye of the Heron(1978) and Marge Piercy's Woman on the Edge of Time(1976) are very much busy with dystopian themes, placing good and bad societies side-by-side, as well as on top of or inside one another.
} 


\section{Pre-print}

do know is that the protagonist Bron, after a brief supportive consultation with a clinician, is able to change male biological features to female ones, acquiring new genitals, uterus, breasts, a slew of morphological and hormonal characteristics, and even converting $\mathrm{Y}$ chromosomes into $\mathrm{X}$ chromosomes ("What will this accomplish?" / "Astonishingly little, actually. But it makes people feel better about it" (Delany 1996 [1976], 222)). Sexual desire can also be altered via "sexual re-fixation" procedures, again against a casually supportive background, suggestive of the longstanding normalization of sexual liberation and sex positivity.

Along with his Nova (1968), Delany's Trouble on Triton is a key forerunner of cyberpunk dystopia, a genre whose characters likewise sometimes access radical transformations of their bodies and their subjectivities with zero or minimal medical gatekeeping. ${ }^{8}$ Of course, these interventions are more empowering for some than for others. Cyberpunk tends to depict bleak, endless cartel capitalism, not avant-garde forms of collective decision-making. The proprietors of cybernetic implant chopshops may not be organising peer-reviewed journals, annual conferences, or complex regimes of professional training and certification, but they are still gatekeepers who demand financial and social capital to access their services. Where the relevance for wellbeing measurement lies is really how somatic and neurological technology can complicate any capability-based approach. While not a typical cyberpunk story, Greg Egan's 1997 'Reasons to be Cheerful' is one excellent illustration. How should wellbeing policy address our capabilities to alter our capabilities? Following life-saving oncolytic-viral treatment, Mark finds himself unable to feel happiness. He receives an experimental neurological prosthesis, based on a composite model of what produces happiness for "males in their twenties or thirties" (Egan 1999, 206). When the model does not adapt as expected, Mark is put in control of it. He must "choose" what makes him happy within parameters initially set by age and gender (Egan 1999, 213). It is presumed that Mark must invent himself through arbitrary leaps of faith, rather than calculations involving the happiness of others.

N. Lee Wood's ' $\sigma$ ' and Edinburgh Action for Trans Health's 'Trans Health Manifesto,' both appearing in 2017, helpfully triangulate these cyberpunk and transhumanist imaginaries. Wood's story vividly brings to life absurd differences in the systems of medical care and welfare support between New Zealand and the USA. Michelle inhabits a system that has been designed to heal.

\footnotetext{
${ }^{8}$ Given that Delany and Afrofuturism are, as MacFarlane (2020) argues, also crucial to the genre's post-Mirrorshades development, perhaps we might simply go ahead and say that Delany created cyberpunk as a queer speculative genre?
} 
Carrie inhabits a system that has evolved to extract economic value from the vulnerable, and happens to include healing as part of its arsenal. Carrie is forced into a flurry of activity to advocate, strategise, and fight for her life. But in another sense, both characters are relatively passive non-participants within their respective healthcare systems. True, Michelle is kept carefully informed of the progress of programme of interventions, and can take her pick of experimental trials; and even Carrie eventually is able to knit herself a Pussyhat and slip out to a protest. But beyond this, neither character experiences much agency in defining her own wellbeing, or governing the health resources which might support it. Healthcare is at best for preserving oneself, not for inventing oneself. Crucially, each is presented with the possibility of her own 'cure' as an individualised happy ending, something of indeterminable significance within wider patterns of health and social inequality (Wood 2017).

By contrast, a non-SFF text, the 'Trans Health Manifesto,' offers one example of the panoply of feminist, queer, and crip projects aimed at more fundamentally transforming the knowledge and governance of healthcare interventions, often under the rubric of democratising and/or de-medicalising care.

We demand medical training to enable us to safely carry out medical procedures \& research for each other, for anyone of us who wants to learn. We will enhance our collective knowledge, so that the means to understand our bodies is universally accessible. [...] We demand research centres \& libraries of knowledge, autonomously \& horizontally organised by and for trans people, in which research subjects are equal participants in deciding the experiments conducted \& the manner in which those experiments are carried out. (Edinburgh Action for Trans Health 2017)

The history of de-medicalisation runs through, for instance, anti-psychiatry and feminist advocacy for reproductive justice from the late 1950s onward. Its recent history has been inflected by a new technoscape of measurement and automated decision-making. As a compressed summary: social media has emerged as the most visible aspect of the digitisation of many areas of economic and social life; data-generating smart devices have grown ubiquitous across the planet; some basic forms of biometric self-tracking have correspondingly risen; behavioural science has re-energised itself as 


\section{Pre-print}

'applied' expertise spanning psychology, economics, and design; and investment continues to pour into Machine Learning research and implementation. These factors converge to produce a new human materiality, one that harbors new dynamics of individuation and collectivity, of expressivity, expertise, legitimacy, recursivity, compossibility, and normativity. This means there arise fierce contests over what we - the new human materiality is after all 'us'! - can legitimately be understood as symptomising, consenting to, sensing, knowing, wanting, reasoning, deciding, authorising, or even deserving, in the data we emanate. These themes are prominent in recent a wave of contemporary dystopian fiction, which Geoff Ryman (2004) might characterize as 'mundane science fiction,' or Kiely and O’Brien (2018) as 'science friction': realist, near-future fiction which often orchestrates collisions of wellbeing, measurement, and even — occasionally — democracy.

\section{Datatopias and Algorithmic Democracy}

Tochi Onyebuchi's 'How to Pay Reparations: A Documentary' (2020) critically explores data-driven techno-utopianism. Underpinned by an appreciation of how "digital technologies are not simply mediating identities of 'difference' but rather are immanent agencies that are racialized assemblages" (Dixon-Román 2016, 483), Onyebuchi’s story adroitly dramatises the disintegration of an experiment in algorithmic slavery reparations, a project dubbed REPAIR. This project is imagined as being based on careful empirical research and quantitative modelling of racism, and financed by de-funding the police force among other means. It produces ambiguous results, as Professor Higgins summarises:

A government can print money, as much as it wants. Don't listen to economists. They're wrong. But a place built on the backs of others needs all of its decision-makers to acknowledge the totality of the wrong. It goes beyond money. [...] Asking an algorithm to do what they wanted it to do would be to assume racism is logical. "If, then." Now, racism has its own internal logic, sure, but it is the logic of nightmares. You can't automate its reasoning. [...]

(Onyebuchi 2020)

Those closely associated with REPAIR regard it as a qualified failure, and some have suffered personal reprisals. Nonetheless there are also hints of improved wellbeing for at least some 


\section{Pre-print}

claimants, and the overall tone is hopeful. If the story has one clear lesson, it is that solutionist projects of reparative justice, confined to the economic realm and without socio-cultural reckoning of racist injustice, are doomed from the start. "For such a redemption project to work, you need this country to admit that it was wrong" (q.v.). Reparation is positioned as a participatory democratic project, both imagined and ongoing. It requires transformation of its participants, rather than mere technical reconfiguration of our relationships. In a companion essay, Charlton McIlwain emphasises the impossibility of mathematically quantifying historic injustices: "we cannot account for, much less model, the moral turpitude, and the social, economic, and political loss of what might have been possible" (McIlwain 2020). Real change demands "a deliberate, revolutionary rebalancing of social, economic, and political power. To even think seriously about doing that requires an exercise of collective human will. And there is no algorithm for that" (McIlwain 2020).

At the same time, 'How to Pay Reparations: A Documentary' does not feel like a straightforward cautionary tale against algorithmic reparations. Rather it is a nuanced attempt to think through the embeddedness of techno-economic relations in social relations, and the practicalities of mobilising new technologies to build collective wellbeing by dismantling white supremacy and other oppressive structures. This is a story that reminds us that possible worlds do not float outside of history, but are immanent agencies with in it, and the ways they are modelled, prototyped, interfaced, and otherwise concretised have bearing on their agency.

Yoon Ha Lee's cozy dystopian thriller 'The Erasure Game' (2019) ventures into slightly more flamboyant and satirical worldbuilding, while still offering grimly comic images of life as a fungible human - intimately surveilled, measured, and groomed within regimes of absurd and unaccountable gamified power. The story's biometric surveillance is well-grounded in existing technology. What is science fictional is how this surveillant-disciplinary apparatus has been socially embedded. A comprehensive system of self-tracking technology and points-based rivalry has been enclosed by a paternalistic centralised state bureaucracy, mediated at the level of communes called 'households' (perhaps analogous to gaming guilds), and reinforced by a uniform culture of compliance. In her introduction, Pam Belluck remarks on the story's "health-obsessed police state" and describes it as "Orwell meets organically grown" (Belluck 2019, 13). Yet surveillance in "The Erasure Game' also differs from what Orwell imagined in 1949. Orwell's O’Brien explains: 


\section{Pre-print}

14

We do not destroy the heretic because he resists us: so long as he resists us we never destroy him. We convert him, we capture his inner mind, we reshape him. We burn all evil and all illusion out of him; we bring him over to our side, not in appearance, but genuinely, heart and soul [...]

(Orwell 2013, 321)

A counterpoint might be Alfred's comment in Katharine Burdekin's classic dystopia Swastika Night (1937): “you can't ever kill all the unbelievers, because, though you can search a man's pockets or his house, you can't search his mind" (xx). By contrast, Lee's story features disciplinary loops that monitor and maintain biometric data within desirable parameters, without necessarily taking a stance on the contents or tractability of anyone's “inner mind” (Orwell 1949: 321). It is a distinction that Shoshana Zuboff dramatises as the shift from "Big Brother" to "Big Other," the "ubiquitous digital apparatus" that "renders, monitors, computes, and modifies human behavior" (Zuboff 2019, 376). For Zuboff, Big Other's characteristic form of power "reduces human experience to measurable observable behavior while remaining steadfastly indifferent to the meaning of that experience" (Zuboff 2019, 376-77).

Dissatisfaction with the classic dystopian imaginary is signalled via the ambiguous figure of the Dragon. The Dragon is the story's villain, a presidential candidate who wants to expand the system of control to zones that are currently exempted, and to stamp out the black markets which provide access to antidepressants, anxiolytics, and birth control. The Dragon also rails against "selfishness" and promotes environmental protections - perhaps an interesting choice of nefarious predilection for a Big Bad in 2018? That said, environmentally omnicidal policies can be and often are conducted in the idiom of environmental sustainability, and maybe the story asks us to presume some greenwashing on the Dragon's part. Either way, the engaging slow-burn worldbuilding in 'The Erasure Game' is rounded off by what seems a curiously anticlimactic revelation: the Dragon is a manufactured persona portrayed by an actor.

By morphing its demagogue into something more multiple, distributed, and micro-targeted, 'The Erasure Game' parallels Zuboff's shift from Big Brother to Big Other, seeking to shake loose the classic dystopian imaginary in which it is still partly entangled. Even so, there may be something uncomfortable and embarrassing about this revelation. Orwell's Big Brother, of course, does not 


\section{Pre-print}

15

really exist either. Moreover, the powerful interests behind the Dragon persona "study numbers to find out what we'll buy and how we'll vote" to further reinforce their power (Lee 2019, 114). This amounts to only a slightly high-flown description of political reality in most contemporary democracies. That is, as most voters know, political decisions are not the work of solitary individuals. They are created by decision-making assemblages. Such assemblages include elected officials as well as lobbyists, advisors, experts, modellers and their models, focus groups, civil servants and other support staff, policy analysts, secret co-conspirators, and so on (maybe even the constituents who have elected them). Within such an assemblage, legal accountability need not coincide with informal arrangements about who decides what. In the extreme, the elected official does become an "actor," focusing on humanising and communicating decisions that largely shaped elsewhere in the assemblage. None of this is really a secret, although occasionally some aspect of it may be successfully framed as a secret in order to manufacture a scandal.

The story's ending apparently celebrates bodily desire. Eat the chocolate, it affirms, in defiance to the claustrophobic culture of compulsory fitness, with all its dubious associations of heroic vitalism. Yet Lee also gives us a deeply uneasy ending. Kimmy and Gray don't really reject their dull and regimented existence to join the resistance. Rather, they are last glimpsed joining the organisation fronted by the Dragon. Kimmy consoles herself that she will now be "pulling the strings" perhaps even pulling them till they one day snap? - but there are hints that she is simply entering a new disciplinary mechanism, one better equipped to steer her wayward instincts. "In my world," explains her mysterious recruiter, "I lose points for leaving a record of my passage" (Lee 2019, 103). In Lee's data dystopia, even de-gamification has been gamified. As Zuboff says, "There is no domination of the soul that displaces all intimacy and attachment with terror-far better to let a multitude of relationships bloom" (Zuboff 2019, 377).

Onyebuchi and Lee's stories might be usefully read alongside Malka Older's 'Candidate Y' (2019), an ambiguously utopian vignette, sharply aware of how assemblages generate democratic actors and horizons of possibility. In 'Candidate Y', a decision support tool elicits significant data from voters and helps them to cast their ballot. In reality, such tools are old hat. Several deft and suggestive details are what make the story SFF. Candidates are anonymised, evaluated solely through their policies. The consultation is publicly funded, takes place at a designated location, and is regulated to 


\section{Pre-print}

16

encourage its independence.' The 'electoral counsellor' participates energetically, not only administering the tool but also explaining its methodology and its data visualisations. The voter is encouraged to observe how outputs might shift in response to inputs. Significantly, the consultation seems to be a normalised and trusted part of the electoral process.

These arrangements mitigate (and thereby foreground) the risk that voters will encounter the tool as a kind of 'black box,' knowable only from its inputs and outputs. That is, the tool's advice may accrue an aura of enigmatic, algorithmic impartiality, appearing more authoritative in some ways while less so in others. New or newly important automation often prompts us to notice the automaticity that was there all along. With the introduction of this novel black box into electoral processes, Older invites us to think about the various other black boxes and grey boxes that are already part of such processes. ${ }^{10}$ These may include, of course, the various opaque and unaccountable political actors just alluded to. But they may also include actors often excluded from the political sphere: animals, plants, ecosystems, and the more-than-human world.

\section{Climate Fiction and De-anthropic Wellbeing}

Sara Ahmed writes, "Happiness shapes what coheres as a world" (Ahmed 2010, 1). This is seldom as straightforward as 'what makes me happy should make you happy', or 'what creates my wellbeing should create your wellbeing.' Nonetheless, wellbeing too shapes what coheres as a world. To explore wellbeing and its measurement is also to explore worlds: how they are built, how they are made, how they enfold and enclose one-another, how a thing may exist across different worlds at once, and how it may mean a very different thing in each. What is utopia for one may be dystopia for another. Yet this old chestnut does not imply that we should abandon attempts to bridge such worlds. Rather, it invites us to think critically about who and what shares any given world. It invites us to explore questions, for instance, of what data sources can legitimately be integrated, what calculative and substantive rationality such data can enact, what alternative economic and ecological systems such data can sustain, and what moral force it can be expected to carry.

\footnotetext{
${ }^{9}$ For example, data about candidates that might want to cut funding to the program is redacted.

${ }^{10}$ Cf. MacFarlane (2000: 305) on Cory Doctorow: 'The utopian thread in Doctorow's literature, like his political work, is based on open source software (and hardware, via 3D printing). Doctorow sees the proliferation of black-box systems as characteristic of a repressive society, and his utopian writing includes blueprints to eradicate black boxes from public life without giving up global networking.'
} 


\section{Pre-print}

17

The transformation of worldbuilding into an applied art - one which shows up in targeted ads, personalised AI, algorithmic filter bubbles, gamified transmedia conspiracy theory such as QAnon, and scientific and artistic experiments employing environmental sensor networks - both co-opts and fruitfully collides with the more resistive and progressive practices that posthumanist and postcolonial theory have characterised as re/worlding, and queer studies as world-making. The making of multiple contradictory social worlds has become a central political concern; whilst at the same moment, we threaten to unmake the planetary world which underpins all these worlds.

The 'Ministry' of Kim Stanley Robinson's The Ministry for the Future (2020) is charged with fighting on behalf of "the world's future generations of citizens" and for "all living creatures present and future who cannot speak for themselves" (Robinson 2020, 26). The organisation interprets this duty to encompass political, legal, and eventually paramilitary means. On behalf of these stakeholders, the Ministry helps to drive global decarbonisation, as well as major projects of geoengineering and rewilding, creating wildlife corridors and other habitats in the spirit of E.O. Wilson's half earth project. The Ministry for the Future is a polyphonic, patchwork novel, sprinkled with short chapters in the form of 'What am I?' riddles, which elaborate on the activities of these rather arbitrarily selected advocates, by giving voice to the more-than-human universe:

By our passing we render the land in ways you need more than ever before. We are caribou, we are reindeer, we are antelope, we are elephants, we are all the great herd animals of Earth, among whom you should count yourselves. Therefore let us pass. (Robinson 2020, 463)

These chapters are unembarrassed by their anthropomorphism. They make no bones that their speaking subjects are the sun, the earth, carbon, blockchain, and herd animals, as construed by bumans. Unless we want the weird otherness of the cosmos to overwhelm us with melancholy, or fill us with an empty and false reverence, we should not be too abashed by a bit of anthropocentrism. In this sense, Robinson's balancing of the human and the more-than-human feels judicious. But as groundwork for the collective management of more-than-human wellbeing, it does have limitations. First, it is inclined to leave the individual human subject relatively intact, rather than considering cyborg swarms of subhuman agencies, or recursive procedures of capabilities modifying capabilities, as in Egan's 'Reasons to be Cheerful'. 


\section{Pre-print}

Second, it sidelines the question of who or what can legitimately speak and act on behalf of whom or what. The measurement of wellbeing has democratic dimensions: it can be in various ways and to various degrees disciplinary, deliberative, agonistic. It can make and unmake political actors, and empower and disempower them. The reindeer may regard themselves as connoisseurs of a good wildlife corridor, but when it comes to the politics of compensating existing landowners to create one, they could use some human help. The caribou do not know how to drill into the glaciers to slow sea level rise. The antelope are not best placed to know which billionaires to assassinate, nor which container ships to sink. It is quite difficult to imagine how such non-humans might be democratically included in activities carried out on behalf of their wellbeing. Difficult to imagine, but not necessarily impossible. It is perhaps an open problem.

\section{Bibliography}

Ahmed, Sara. 2010. The Promise of Happiness Durham: Duke University Press.

Barbrook, Richard, and Andy Cameron. 1995. 'The Californian Ideology'. Mute, 1995. https://www.metamute.org/editorial/articles/californian-ideology.

Beer, David. 2016. Metric Power. Palgrave Macmillan UK. https://doi.org/10.1057/978-1-137-55649-3.

Belluck, Pam. 2019. 'Introduction'. In Take Us to a Better Place: Stories, edited by Pam Belluck and Roxanne Gay. Robert Wood Johnson Foundation.

Bennett, Jane. 2010. Vibrant Matter: A Political Ecology of Things Durham: Duke University Press.

Bentham, Jeremy. 2000. Principles of Morals and Legislation Kitchener: Batoche Books.

Crossen, Kendell Foster. 1954. Year of Consent New York: Dell.

Dasgupta, Partha. 2021. Economics of Biodiversity:The Dasgupta Review. London: HM Treasury.

Delany, Samuel R. 1996. Trouble on Triton: An Ambiguous Heterotopia. Middletown, Connecticut: Wesleyan University Press.

Dewey, John. 2016. The Public and Its Problems: An Essay in Political Inquiry. Edited by Melvin L. Rogers. Athens, Ohio: Swallow Press.

Dixon-Román, Ezekiel. 2016. 'Algo-Ritmo: More-Than-Human Performative Acts and the Racializing Assemblages of Algorithmic Architectures'. Cultural Studies $\leftrightarrow$ Critical Methodologies 16 (5): 482-90. https://doi.org/10.1177/1532708616655769.

Edinburgh Action for Trans Health. 2017. 'Trans Health Manifesto'. 2017. 


\section{Pre-print}

19

https://edinburghath.tumblr.com/post/163521055802/trans-health-manifesto.

Egan, Greg. 1999. 'Reasons to Be Cheerful'. In Luminous. London: Millenium.

Ekbia, H. R., and Bonnie A. Nardi. 2017. Heteromation, and Other Stories of Computing and Capitalism Acting with Technology. Cambridge, MA: MIT Press.

Escobar, Arturo. 2018. Designs for the Pluriverse: Radical Interdependence, Autonomy, and the Making of Worlds. New Ecologies for the Twenty-First Century. Durham: Duke University Press.

Godwin, Tom. 2011. 'The Cold Equations'. Lightspeed, 19542011.

Haraway, Donna Jeanne. 2008. When Species Meet. Posthumanities 3. Minneapolis: University of Minnesota Press.

Jenyns, Soame. 1758. A Free Inquiry into the Nature and Origin of Evil: In Six Letters To ---.3rd ed. London: R. and J. Dodsley.

Johnson, Samuel. 1757. 'Review of Soame Jenyns, A Free Enquiry into the Nature and Origin of Evil'. Literary Magazine, 1757. http://jacklynch.net/Texts/jenyns.html.

Lacey, Catherine. 2021. 'Congratulations on Your Loss'. Slate Magazine, 24 April 2021. https://slate.com/technology/2021/04/catherine-lacey-congratulations-on-your-loss-shortstory.html.

Latour, Bruno. 2004. Politics of Nature: How to Bringthe Sciences into Democracy. Cambridge, Mass: Harvard University Press.

Lee, Yoon Ha. 2019. 'The Erasure Game’. In Take Us to a Better Place: Stories, edited by Pam Belluck and Roxanne Gay. Robert Wood Johnson Foundation.

McGregor, Allister. 2018. 'Reconciling Universal Frameworks and Local Realities in Understanding and Measuring Wellbeing'. In The Politics of Wellbeing:Theory, Policy and Practice. London: Palgrave Macmillan.

McIlwain, Charlton. 2020. 'Racism Cannot Be Reduced to Mere Computation'. Slate Magazine. 29 August 2020.

https://slate.com/technology/2020/08/algorithms-artificial-intelligence-racism-reparationshistory.html.

Older, Malka. 2019. 'Candidate Y'. In ... And Other Disasters. Baltimore, MD: Mason Jar Press.

Onyebuchi, Tochi. 2020. 'How to Pay Reparations: A Documentary'. Slate Magazine. 29 August 2020. https://slate.com/technology/2020/08/how-to-pay-reparations-short-story.html.

Orwell, George. 2013. Nineteen-Eighty-Four: The Annotated Edition. London: Penguin.

Protevi, John. 2009. Political Affect: Connecting the Social and the Somatic. Minneapolis, MN: University of Minnesota Press.

Qiufan, Chen. 2019. 'A History of Future Illnesses'. In Broken Stars: Contemporary Chinese Science Fiction in Translation, translated by Ken Liu. London: Head of Zeus. 


\section{Pre-print}

20

Rancière, Jacques, Davide Panagia, and Rachel Bowlby. 2001. 'Ten Theses on Politics'. Theory \& Event 5 (3). https://doi.org/10.1353/tae.2001.0028.

Roberts, Adam. 2014. London: Gollancz. Bête.

Robinson, Kim Stanley. 2020. The Ministry for the Future. First edition. New York, NY: Orbit.

Taylor, Astra. 2018. 'The Automation Charade'. Logic Magazine, 2018. https://logicmag.io/failure/the-automation-charade/.

Varoufakis, Yanis. 2021. Another Now: Dispatches from an Alternative Present. Vintage.

Wood, N. Lee. 2017. ‘ London: OR Books.

Zuboff, Shoshana. 2019. The age of surveillance capitalism:the fight for a buman future at the new frontier of power.

https://www.overdrive.com/search?q=101A5304-CA07-4629-84B6-EE6F0A2B0EDC. 